\title{
GENERATIONAL DYNAMICS, SOCIAL POSITIONS AND POLITICAL BEHAVIOR
}

\author{
KIMI TOMIZAKI ${ }^{1}$ \\ Maria Gilvania Valdivino Silva²
}

\begin{abstract}
We present, in this paper, a discussion of an eminently theoretical character, with methodological implications, regarding the formation and transformation of opinions, behaviors, and political attitudes from the processes of transmission and inheritance of social positions, throughout the course of life. Thus, political behaviors, constituted according to multiple variables, would also be determined by the realization or frustration of intergenerational projects of transmission, and inheritance of social positions, which is experienced in different ways at different stages of life. To this end, we rely on a discussion with French authors, in particular Pierre Bourdieu, Annick Percheron and Anne Muxel, as well as on the dialogue with the Brazilian bibliographic production of the last decade on the subject.
\end{abstract}

Keywords: Political socialization. Political behaviour. Generations. Social positions. Age.

\section{DINÂMICA GERACIONAL, POSIÇÕES SOCIAIS E COMPORTAMENTO POLIÍTICO}

RESUMO: Apresentamos, neste artigo, uma discussão de caráter eminentemente teórico, com implicações metodológicas, a respeito da formação e da transformação de opiniões, comportamentos e atitudes políticas a partir dos processos de transmissão e herança de posições sociais, ao longo do curso da vida. Assim, os comportamentos políticos, constituídos em função de múltiplas variáveis, seriam também determinados pela realização ou frustração de projetos intergeracionais de transmissão e herança de posições sociais, o que é vivenciado de modo diverso nas diferentes etapas da vida. Para tanto, apoiamos-nos em uma discussão com autores(as) franceses(as), em especial, Pierre Bourdieu, Annick Percheron e Anne Muxel, bem como no diálogo com a produção bibliográfica brasileira da última década sobre o tema.

Palavras-chave: Socialização política. Comportamento político. Gerações. Posições sociais. Idade.

The discussion presented in this article is part of the research project: Quando (Quase) Tudo se Desfaz: as Transformações do Comportamento Político da Categoria Metalúrgica do ABC Paulista e Suas Relações com Educação e Trabalho (Fapesp - Processo n. 2020/07727-7), coordinated by Kimi Tomizaki.

1.Universidade de São Paulo - Faculdade de Educação - São Paulo (SP), Brazil - E-mail: kimi@usp.br

2.Instituto Universitário de Lisboa - Centro de Investigação e Estudos de Sociologia - Lisboa, Portugal. E-mail: maria.gilvania@iscte-iul.pt Section Editor: Adriana Dragone Silveira 


\title{
DINÁMICA GENERACIONAL, POSICIONES SOCIALES Y COMPORTAMIENTO POLÍTICO
}

\begin{abstract}
RESUMEN: En este artículo presentamos una discusión de carácter eminentemente teórico, con implicaciones metodológicas, sobre la formación y transformación de opiniones, comportamientos y actitudes políticas a partir de los procesos de transmisión y herencia de posiciones sociales, a lo largo del curso de la vida. Así, los comportamientos políticos, constituidos por múltiples variables, también son determinados por la realización o frustración de proyectos intergeneracionales de transmisión y herencia de posiciones sociales, que se vive de manera diversa en las etapas de la vida. Para ello, nos apoyamos en una discusión con autores franceses, en particular, Pierre Bourdieu, Annick Percheron y Anne Muxel, y en el diálogo con la producción bibliográfica brasileña de la última década sobre el tema.
\end{abstract}

Palabras-clave: Socialización política. Comportamiento político. Generaciones. Posiciones sociales. Edad.

\section{Introduction}

A

$s$ democratic regimes are more intensely questioned (and at risk), increases the demands surrounding the challenging intellectual and political task of discussing the effects of educational processes, especially schooling, on the formation of political behaviors of citizens. As we have already discussed in previous publications, we believe that political behaviors, or, more broadly, the ways in which individuals and groups perceive and react to events of "political nature", can be considered, among other factors, also as a result of the educational processes developed in various socializing instances (family, school, work, church, unions, parties, associative spaces, etc.). Therefore, in order to carry out an analysis of the effects of education on political behavior, we would have to carry out two theoretical and methodological movements: 1) understand the nature and characteristics of the different formative processes of perception and assessment schemes of the reality of individuals and groups; and 2) to analyze the effects of social, economic and political circumstances, which would also include changes in the political field itself (TOMIZAKI; CARVALHO-SILVA; SILVA, 2016).

In this article, in order to deepen this debate, we will dedicate ourselves to present an eminently theoretical discussion, with methodological implications, on the formation and transformation of political behaviors as part of the processes of transmission and inheritance of certain social positions. Therefore, we assume that the perspectives (individual, family and class) in terms of possibilities or limits of reproduction or alteration of social position, and the strategies associated with them, have important effects on educational processes in general and, therefore, also on the formation of political behavior. It is, therefore, an unusual approach in Brazil, which relates such behaviors to the realization or frustration of intergenerational projects of mobility or conservation of social positions, which can be experienced in very different ways depending on the stage of life. In other words, we will discuss the development of political opinions, behaviors and attitudes ${ }^{1}$ from two dimensions that have an important influence on educational processes and the relationship with politics: 1) the transmission and inheritance of social positions of individuals and groups; and 2) the different stages of life, both considered in the context of the dynamics of intergenerational relations ${ }^{2}$.

In order to carry out this theoretical exercise, we rely on the contributions of different authors, especially Pierre Bourdieu, Annick Percheron and Anne Muxel, whose works allow us to support the 
aforementioned hypothesis. In addition, we conducted a dialogue with the Brazilian bibliographic production of the last decade on the subject. To this end, a consultation was carried out with the electronic library Scientific Electronic Library Online do Brasil (SciELO Brasil) using the following keywords: "educação política"; "educação e política"; "educação e comportamento e política"; "educação para a democracia”; "socialização e política"; "socialização política"; "comportamento político"; "atitudes políticas"; "mobilidade social" ("Political education"; "Education and politics"; "Education and behavior and politics"; "Education for democracy"; "Socialization and politics"; "Political socialization"; "Political behavior"; "Political attitudes"; "Social mobility"). After reading all articles found, we selected those that spoke directly with the theme of this publication, which totaled 36 articles and, based on the citations of the authors of these articles, we also incorporated three doctoral theses and a dissertation of master's degree.

Regarding the articulation between the works of the French authors mentioned, it is necessary to highlight that such a debate requires, on the one hand, to consider their divergences and, on the other, the possibility of delineating a intersection zone between their contributions on the topic in question. In this sense, we start by discussing the notion of political socialization, whose specificity is called into question by Bourdieu, who, starting from the observation that there is a close relationship between social order and political order, does not conceive that a "political education" it can exist independently of the "general" processes of production of the provisions, which would form the basis of judgments and political practices.

If we do not always observe, between the position in the social space and political opinions, simple and direct relations as in other domains, it is certainly in this field, much more than in any other, that the weight of the social trajectory is very important as that, for example through the experience of ascension or decline, it orders all perception of the social world and, especially, of the future of this world (BOURDIEU, 1977, p. 85).

Percheron, although he agreed that it would not be possible to separate political socialization from other socialization processes, he considered it feasible to apprehend some specificities of the formation processes of political behavior. In this sense, the author points out that Bourdieu would operate with a restrictive definition of politics, discussing primarily the characteristics and dynamics of the political field itself and the conditions for the formation of the so-called "political competences" (which are also social competencies) of those who feel whether or not they can express their opinions on "political issues" (PERCHERON, 1993; BOURDIEU, 1977; 2011).

According to Bourdieu, the social space is multidimensional and functions as a macro field of forces (and struggles), which houses, inside, a multiplicity of more specific social field $s^{3}$, in which individuals and groups are distributed according to the possession of certain capitals, which can be economic, cultural, social and symbolic. Thus, some agents, due to the positions they occupy in the social space, are closer to others and, therefore, would be more likely to internalize similar dispositions and positions, guided by an habitus $^{4}$ of common class (BOURDIEU; WACQUANT, 1992). In this perspective, the political field is the "place where - in competition between the agents involved in it - political products, problems, programs, analyzes, comments, concepts, events are generated, among which ordinary citizens, reduced to 'consumers' status, they must choose" (BOURDIEU, 2005, p. 164). Therefore, the political field has its own internal logic and disputes; however, unlike other fields, the political field can never be completely autonomous, since it depends on the vote referendum to exist, which forces it to refer in different ways to the "profane" who have the (relative) power to determine the composition and organization of the field (BOURDIEU, 2005, p. 164). 
In another sense, operating with a broader conception of politics, Percheron argued that studies on political socialization could achieve some specificities of the "processes of political construction" in everyday life, through empirical research that abandoned the idea of an unique schemed and homogeneous socialization.

\begin{abstract}
Even if the fundamental mechanisms do not change, the rhythms and strong times of socialization are very likely to be different: early childhood, for example, will lose its importance for the benefit of childhood and adolescence. Even if the main agents remain identical, their actions run the risk of not being complementary [...]: in a number of cases, for example, the family and the school may become competing agents, even antagonists. [...] These particularities are sufficient to support the relevance of a study on the conditions of production of representations and of properly political practices (PERCHERON, 1993, p. 28).
\end{abstract}

It was in these terms that Percheron directed his research to the understanding of the political universe of children and adolescents, which allowed him to think about political socialization from some premises: 1) the socialized is not a passive being and all socialization is the result of the transaction between individuals and society - thus, all socialization also includes "creation" and "choices", so it will never be a simple reproduction; 2) socialization is a process, always unfinished, composed of stages linked to the affective and cognitive development of individuals, changes in their surroundings and the diversity of experiences; 3) political socialization is a dimension of a broader process: the construction of social identity - that is, the acquisition of symbolic codes from different groups with which individuals identify, which can favor both conformity to the established order and the deviation, tradition or changes. Finally, it is necessary to highlight Percheron's contribution to the analysis of the relationship between age, generation effects and political attitudes, which is prolonged and deepened in the works of Anne Muxel (MAYER, 1993; LAGROYE, 1994; DUBAR, 2002; MUXEL, 2011).

From these premises, we arrive at what appears to be a second important divergence between Percheron and Bourdieu, which concerns the possibility of autonomy and creation of the socialized ones within the scope of socialization processes. It is, therefore, necessary to consider the criticisms directed at the concept of habitus, as defined by Bourdieu, as excessively rigid or deterministic, as well as the prevalence of primary socialization over other moments of socialization. In fact, Bourdieu argues that primary socialization creates "products" that are particularly stable and resistant to transformation, irreversible dispositions, we could say, although not immutable. In this sense, the habitus, although it has a durable nature, does not constitute a set of crystallized dispositions, and can be reconfigured in other stages of life, depending on the experiences with which individuals are confronted. However, such reconfigurations would depend on very specific socio-historical circumstances, marked by the mismatch between the production conditions and the working conditions of the habitus. (BOURDIEU, 2009; DARMON, 2015; SINGLY, 2009; VANDENBERGHE; VÉRAN, 2016; VANDENBERGHE, 2016; LAHIRE, 2001).

According to Peters (2013), in the work of the French sociologist, with the exception of the exercise of "autosocioanalysis", supported by the tool of sociology, only the mismatch between the dispositions of the agents and their acting/experience environments would allow the emergence of founded actions in reflection, which would deny the possibility of the reverse process, that is, that the exercise of reflexivity by the actors would result in changes in the relationship between habitus and the structuring of social space. Thus, without giving up Bourdieu's theoretical construct, the author points out the limits of the notion of habitus with regard to the admissibility that actors can have a relative reflective and conscious control over their own practical 
dispositions of conduct, a fact that, even, it would be, to some extent, demonstrated by the book The Misery of the World, organized by Bourdieu.

But what a book like The Misery of the World also shows is that, even in situations where there is, at least for all practical purposes, no resistance to structural domination and the unequal distribution of resources, the habitual complicity of the dominated with the the domination that is observed in the domain of social practice can coexist with (and perhaps even intensify) a reflexive, very conscious and, at times, discursively articulated experience of acute criticism and painful rejection of the very social conditions of existence (PETERS, 2013, p. 62).

Thus, considering such criticisms and also Bourdieu's contributions to the analysis of the transmission processes of positions and dispositions, in this article we will highlight the double movement pointed out in the studies of Percheron and Muxel. On the one hand, the affirmation of the relevance of the mechanisms of intergenerational inheritance of political behaviors promoted in the family sphere (considered here in relation to the transmission of social positions), which Muxel calls "intimate politicization", whose strength is located in the fact that the conditions of transmissibility of political choices in the family operate implicitly, through diffuse impregnation, in which values and opinions are transmitted that will impact future experiences. On the other hand, the consideration that, throughout life, political behaviors will undergo successive adjustments and readjustments, depending on the circumstances (historical, political, social or biographical) and the encounters (personal and institutional) that mark the course of the life, materializing in new positions, choices and political affiliations (MUXEL; PERCHERON, 1985; PERCHERON, 1987; 1988; MUXEL, 2008; 2018).

\section{Political Behavior and Social Position Transmission Processes}

If there is a consensus in the scope of generational studies, it concerns the fact that older generations have a great propensity to create strategies to guarantee the transmission of their social positions or to promote the conditions for the new generations to reach positions that the first ones would like to have accessed; what is expressed by parents out of a desire that their children suffer less or encounter less difficulties than themselves (ATTIAS-DONFUT, 1988; 2000).

Thus, intergenerational social mobility permanently structures relations between generations and it guides, notably, the forms and contents of family solidarities. For example, financial transfers made by parents increase if there is a risk of social degradation of children and care for grandchildren is intensified to encourage the professional advancement of young mothers (ATTIAS-DONFUT; WOLFF, 2001).

In this sense, the study of intergenerational relations necessarily involves discussing the possibilities or limits of social mobility, which, according to Attias-Donfut and Wolff (2001), must encompass both the objective dimension of the transmissions and the subjective perception of differences or similarities between the social positions of parents and children, thus proposing the notion of "subjective social mobility", defined as the feeling of having been successful or unsuccessful in life compared to their ancestors and descendants.

Therefore, assuming the central role that the transmission and inheritance of social positions have in intergenerational relationships, as well as in the ways in which each one can objectively and subjectively 
assess "their place" in the world and within their lineage (family and social), we believe that it is impossible to adequately understand the processes of formation and transformation of political behaviors without these being analyzed in the light of the perspective of realization or frustration of the processes of intergenerational transmission of social positions(TOMIZAKI, 2013; SILVA; TOMIZAKI, 2016).

In this sense, it is worth noting that it is not a matter of simply relating the formation and transformation of political behaviors to the class conditions of individuals and groups at a given fixed or static moment, but of thinking about these processes in a relational and "moving" way. According to Bourdieu, society can be defined as a multidimensional space of different social positions, constituted according to the distribution of properties between individuals and groups, which gives them power in relations with others. Such properties are distinct forms of capital (economic, cultural, social and symbolic), which must be analyzed, on the one hand, by a synchronous cut of the social structure - that is, the analysis of the volume and composition of the capital of groups and individuals - and, on the other hand, for a diachronic cut, which considers each position as a specific point in the trajectory between a source and a destination (BOURDIEU, 2005).

The social position of an individual or group in the social structure can never be defined only from a strictly static point of view, that is, as a relative position ("superior", "average" or "inferior) in a given structure and at any given time. The point of the trajectory that a synchronous cut perceives always contains the direction of the social trajectory. Therefore, under penalty of letting go of everything that concretely defines the experience of the position as a stage of ascension or descent, as promotion or regression, it is necessary to characterize each point by the differential of the function that expresses the curve, that is, throughout the curve (BOURDIEU, 2004, p. 8, italics by the author).

Therefore, the social position cannot be defined only by the place occupied by individuals and groups in the economic structure, in their relationship with other classes, or strictly by the possession of certain capitals (economic, cultural, social and symbolic). It is necessary to consider the "direction of the trajectory" of each individual or group (conservation, rise or decline), as well as their objective and subjective evaluations of the conditions of possibility of maintaining or altering that trajectory, which results in specific ways of constituting strategies for the present and projects for the future that would have important effects on political behaviors and positions, as governments, political institutions, public policies, parties and even specific political characters (notably in positions of the Executive Branch) can be conceived as responsible for the changes in living conditions and access to certain goods and rights.

In a 1978 article, Daniel Boy points out that the effects of intergenerational social mobility on the political behavior of individuals has been the subject of studies, especially in the United States and England, since the 1950s and that, in general, such studies tended to agree that individuals who performed social mobility (upward or downward) adopted an intermediary political behavior between the "origin group" and the "arrival group". However, the author points out that more accurate studies of the mechanisms related to this phenomenon demonstrate that the effects of social origin on political behavior and attitudes are not only related to the distance between the position of parents and children, but also according to nature and conditions of the social trajectory carried out. Thus, in view of the difficulties in establishing quantitatively the weight of the variables capable of defining such trajectories, especially with regard to the "family political tradition", Boy points out that studies that relate political behavior and social class should take a more dynamic perspective, since that class belonging may not only be limited to the individual's current situation, but also includes the assessment of his position in relation to the position of his parents, as well as his "social hope" - that is, the anticipation of 
his probable or possible future. Therefore, meeting the discussion of the objective and subjective perceptions of social mobility, Boy is aware of the need for future perspectives, which may be of hope or frustration, to also be considered in analyzes of social mobility between generations. In more recent studies, Peugny (2006; 2014), who is dedicated to analyzing the political consequences of downward intergenerational mobility among employees in France, points out that there is no single and systematic effect in this process, but it is possible to perceive an original recomposition of the axiological universe of this group, in which the feeling of frustration that accompanies social decline stands out; the transformation of economic discourse (which mixes criticism of economic liberalism and the attack on those «assisted» by public policies); and a tendency to vote on the far right.

Without pretending to exhaust the discussion on such a complex topic, we are interested in highlighting the relevance (and the need) of studies that focus on the ways in which educational processes, which mediate intergenerational transmissions (including ways of perceiving politics), are influenced by the objective and subjective evaluations that individuals and groups make of their social trajectories in a game of mirrors between the past, the present and the future perspectives.

In the analysis of the national bibliography, it is important to highlight that, especially in the area of Education studies, there is still a research gap that deals more specifically and in detail with the role of intergenerational transmission and inheritance processes in the formation and transformation of political behaviors of individuals and groups. However, important studies, mostly quantitative and in the field of Political Sciences, shed light on a series of correlations between the political behaviors of the Brazilian population, with emphasis on electoral behavior, and different dimensions of social position, such as income, education, sex, age, level of information and generational effects (ROCHA, 2018; 2020; RENNÓ; BORBA, 2019; FUKS; CASALECCHI, 2018; FUKS; PAULINO; CASALECCHI, 2018; SILVA, 2019). It is also worth noting that, in the last decade, research on political behavior in Brazil was strongly marked by the discussion around the effects of the reduction of inequalities and poverty, as well as the emergence and weakening of "Lulism", related, among other factors, to the rise of "antipetismo" (diffuse movement, present in different sectors of society, contrary to the Workers' Party of Brazil). (SAMUELS, 2004; TERRON; SOARES, 2010; BORGES; VIDIGAL, 2018; RIBEIRO, 2011; RIBEIRO; CARREIRÃO; BORBA, 2016).

Regarding the role of social class in the constitution of political behaviors, Brazilian studies tend to confirm the relevance of this variable, also pointing to an inflection in the academic literature on the relationship between voting and social class, which starts to revalue social class as a source of vote orientation, contradicting the consensus established over the 1980s and 1990s about the loss of importance of class membership as an explanatory variable of electoral behavior in advanced democracies. In the same sense, other studies discuss how the perception of social ancestry or an improvement in the economic situation of families is decisive in defining the vote (FERRAZ, 2009; PEIXOTO; RENNÓ, 2011; RENNÓ; TURGEON, 2016).

Regarding the effects of schooling on political behavior, Dias and Kerbauy (2015), when analyzing the 2014 presidential elections, conclude that schooling is a variable capable of influencing citizens' behavior and, although political interest and participation in the Brazil are very low, the more educated are more interested, informed and participative. In addition, they are the most educated who tend to support political institutions and democracy as the best form of government. However, in this same group are found the highest levels of dissatisfaction with the functioning of democracy in Brazil and even statements of support for dictatorial regimes in specific circumstances, such as economic or political crises, are found. Still on the issue of the effects of schooling, it is important to consider the work of Schlegel (2010), which points out that the correlation between increased schooling and appreciation of democracy had been losing strength in the last decade in Brazil, highlighting the need to consider other dimensions of access to school, such as the quality of teaching, generational effects and the educational environment. 
Thus, these studies demonstrate that the effects of educational processes on the constitution of political behaviors, including schooling, do not have an unequivocal logic, which requires that such processes be discussed in relation to other variables, such as social positions, political and economic conjunctures and political cultures. In this sense, the researches that discuss the ambivalent adhesion of the Brazilian population in relation to the democratic regime stand out, since it is possible to register a certain inconsistency between the statement that democracy would be the best form of government and the devaluation of practices and principles democratic (such as free elections, appreciation of the vote and different forms of political participation). The data show that economic development, the reduction of inequalities, the good functioning of the democratic regime and the longevity of the democratic experience are fundamental for the development of "democratic cohesion"; that is, the formation of a coherent democratic "belief system", in which attitudes and voting options converge to support democratic principles and values (GIMENES; BORBA, 2019; FUKS, CASALECCHI; RIBEIRO, 2019; FUKS et al., 2016).

Undoubtedly, from Brazilian studies, we can access precious data about the characteristics of the political behavior of Brazilians, their nuances and contradictions, in addition to the diversity of theoretical and methodological of this type of study. However, we still devote little to understanding the mechanisms for the formation of such behaviors, which would probably require more qualitative research, in addition to more precise cuttings regarding social position (in its objective and subjective dimensions) and its implications for ways of life and perception of the reality of individuals and groups.

\section{Political Behavior Throughout Life: Continuities and Breaks}

Based on the discussion previously held on the importance of the processes of transmitting social positions in the formation and transformation of political behaviors, in this section we will discuss how these processes are experienced differently by individuals and groups at different stages of life, since, from different "places" in the relationship between generations, individuals can perceive and evaluate, in a divergent way, the possibilities of carrying out intergenerational projects, which is also influenced by the nuance of ages. According to Ortega y Gasset, it is necessary to distinguish two notions in the study of generations: contemporaneity and age equality, since contemporary individuals who belong to different generations coexist in societies and, therefore, perceive events with different "shades", constituted according to age (ORTEGA y GASSET, [1923]1981).

In this sense, the notion of age, which Percheron (1993) defined as the condensation, in the same abstract notion, of biological, social and affective trajectories, has an important place in the discussion of the stages of life; and, even considering that there are no "pure effects" of age on political behavior, there is no doubt that we cannot ignore this dimension. Thus, age introduces in the analysis of political behaviors the fundamental parameter of time and duration of existence, even though its role in the structuring and evolution of political attitudes and behaviors is neither regular nor easily identifiable. According to Muxel (2011), some demographers consider age an "intermediate variable", neither dependent nor independent: a variable that reinforces or mitigates the effects of other variables considered more decisive. Thus, the author proposes that age be considered in a broader and more complex framework, based on three time scales: the "age-period" (historical temporality); "the age-generation" (generational temporality); and "age-biography" (individual temporality).

Thus, taking into account the complexity of the time scales involved in the development of life stages, we consider the notion of life course to be particularly operational, which, according to Alwin, Felmlee and Kreager (2018), refers to the set of interconnected paths traveled by an individual throughout 
life in different domains - for example, family, sex, race, religion, as well as place of birth and residence, work, economic conditions, among others. Such paths, in turn, would be marked by sequences of events in the different stages of life (biological and social), from birth to death. Evidently, the transitions and exposures to the different events that individuals go through would not be the same for everyone, since they would depend on other variables, such as social class conditions, the historical period and the social organization. (ALWIN; FELMLEE; KREAGER, 2018; BERNARDIA; HUININKB; SETTERSTEN; 2019; ELDER; GIELE, 2009).

A considerable part of the studies on the life course concentrates on one phase of life or on the transition between two phases, with great emphasis on the transition from youth to adult life; such studies make up the so-called life course perspective (NICO, 2011; ALWIN; FELMLEE; KREAGER, 2018).Thus, as it is possible to deduce, "time (or temporality) is fundamental to the perspective of the course of life, and should be considered as a unit of individual, social and historical registration" (NICO, 2011, p. 14). Therefore, individuals would follow different interconnected paths in each phase of their life, in which different socialization processes develop, and, in this sense, we believe that the use of the life course perspective can be particularly useful for the understanding of political behaviors, because the paths taken by individuals promote experiences and expectations nuanced by the stages of life, as well as the challenges that each of them imposes on individuals and on the processes of transmission and inheritance.

In the analysis of the national bibliography, we identified that, in general, the works that discuss the relationship between processes of political socialization, political participation and the stages of life do so by focusing on a specific phase, with emphasis on youth - which, in turn, would be closer to the perspective of the course of life, although it is not always clear with what definition of age, stage of life or generation the authors are operating.

Starting with childhood, we can say that studies on the relationship between children and politics are not common not only in Brazil, especially from the point of view of political participation in childhood. According to Muxel (2018), there is a tendency towards the sacralization of childhood as opposed to the negative image of politics and, therefore, parents tend to consider that political positions should be acquired autonomously and, preferably, after childhood. At the same time, most parents believe that political education should be a family, not a school concern ${ }^{6}$. However, research carried out by Annick Percheron $(1974 ; 1993)$ indicates that children apprehend elements of the political universe from a very early age, through the implicit transmission of political opinions and values within the family, which is permeable to such matters through media (and, more recently, over the Internet).According to Muxel (2008; 2018), political discussions continually penetrate the intimate family environment (especially in electoral or crisis periods), in which children capture, apprehend and adapt information, reactions and attitudes of adults, in a regime of affection, assimilating, at the same time, affective and political records and references that have an important influence on the later stages of political socialization.

In Brazil, Castro and Grisolia (2016) state that the absence of studies on politics and childhood is linked to a conception of child subjectivity, which is mostly understood as passive and in the process of formation - therefore, marked by incompleteness, disregarding that children they are also political subjects, "of speech and rights", with public roles that must be considered in their particularities. Lima (2020), in turn, analyzes the civic education program Câmara Mirim - Plenarinho ("Chamber of Children - Small Plenary") and its importance for the formation of a democratic political culture in Brazil, highlighting the need to offer children an educational environment that promotes effective public engagement, as well as conditions for public participation in democratic environments, in which children can hear and be heard.

Regarding the importance of intergenerational relations and, therefore, also of the family as a socializing instance in the processes of constitution of political behaviors, studies on the transmission 
between parents and children of ways of relating to society stand out in the national bibliography, contextualized in specific political cultures, such as in the ABC Paulista region or in the south zone of the city of São Paulo (SILVA, 2017; MORENO, 2018). Other articles, although not specifically addressing the study of the family institution, highlight the importance of family transmission in all processes of formation of political behavior (FUKS; PEREIRA, 2011; FUKS, 2011; 2012; SAMPAIO; SIQUEIRA, 2013).

Advancing to the next stage of life, the themes and perspectives of studies on youth in Brazilian literature are varied: conditions of existence and social position of young people; specifics of the youth experience; family; religion; peer groups; schooling; the media and the Internet. In addition, different spaces of participation are also addressed: parties, student entities and social movements; religious and identity movements, such as the LGBTQ + movement (OKADO; RIBEIRO; LAZARE, 2018; MORENO, 2018; BRENNER, 2018; GROPPO; BORGES, 2018; BAQUERO; BAQUERO; MORAIS, 2016; TOMIZAKI; DANILIAUSKAS, 2018).

Another aspect to be highlighted among studies that take youth as a privileged stage of life in order to understand formation, understanding and the relationship with politics is the relevance of the analyzes of civic education programs or education for democracy, carried out, preferentially and almost exclusively during youth. These are studies that analyze the effects of participation in these programs on the behavior and political participation of young people. The main programs analyzed are: Parlamento Jovem de Minas Gerais (Youth Parliament of Minas Gerais); Parlamento Jovem Brasileiro (Brazilian Youth Parliament); Câmara Mirim - Plenarinho (Chamber of Children - Small Plenary); and other education for democracy programs in force at the National Congress. These studies have in common the defense that education (formal or informal) is fundamental, perhaps the main means, for the acquisition of cognitive elements that enable the understanding of politics and democracy, thus contributing to the consolidation of democratic regimes (BARROS, 2016; MARTINS; BARROS, 2018; SAMPAIO; SIQUEIRA, 2013, FUKS; PEREIRA, 2011; FUKS, 2011; 2012, 2014; OLIVEIRA; BIANCHINI, 2017).

Following the stages of life, we move into adulthood, when there is a greater tendency to stabilize learning and to consolidate political identities, which does not mean the impossibility of changes (MUXEL, 2011; 2018). Among the few studies that approach adult life in more depth, we highlight those that are focused on analyzing the processes of formation and transformation of political behaviors through engagement in social movements, especially the Movimento dos Trabalhadores Sem Terra -MST (Landless Workers Movement) and the Movimento dos Trabalhadores Sem Teto- MTST (Homeless Workers Movement), as well as for the voting experience (TOMIZAKI; CARVALHO-SILVA; SILVA, 2016; RODRIGUES, 2017; BASTOS, 2017; CARVALHO-SILVA, 2018; ALMEIDA, 2017).

In the sequence, there is old age, a stage of life in which political identities would tend to be formed and more strongly consolidated. A noteworthy factor is the almost absence of studies that discuss the political behavior of old people or their role in shaping the ways of perceiving and acting in the politics of new generations, which may indicate, as in the case of of childhood, a limited perspective in relation to the political and social powers of the last stage of life, which, thanks to the increase in life expectancy, becomes increasingly long. In this sense, it is necessary to highlight two aspects of this debate: on the one hand, if the educational processes are not limited to the school / family environment or to a single stage of life, we learn, assimilate or re-signify political opinions and behaviors at all stages of life, although with different intensities - therefore, also in old age. On the other hand, we must consider that the old, as they have lived experiences in other times and social spaces, can contribute 
important learnings for the new generations, such as support for democracy, a phenomenon that was identified in recent works on Latin America (FUKS; PAULINO; CASALECCHI, 2018).

This result is instigating, as it contradicts the idea that younger people would be more likely to develop democratic attitudes. In the specific case of Latin America, the data points in the opposite direction: older people have a more democratic profile than young people. A plausible explanation is that the older generations are precisely those who have experienced military atrocities and those who have experienced the struggle for direct elections, political and social rights. In this sense, they would have rooted democratic values more solidly than later generations, who lived only in democracy and who did not participate in the transition process(FUKS; CASALECCHI; RIBEIRO, 2019, p. 21-22).

Again, it is not a matter of looking for the "pure effects of age" or a certain stage of life on political behaviors, but of understanding such behaviors as a result of a combination of several factors, including historical and contextual ones.

\section{Final Considerations}

We only have our history and it is not ours. José Ortega y Gasset

Just as our stories are not only ours, forming part of broader stories, which stretch in time and space, towards the past and also into the future, our ways of relating to the universe of politics are also tributaries of multiple stories : the stories of the generations that preceded us; the stories lived in the present, situated in specific political, economic and social configurations (and which escape us); of the stories we can conceive for the future (our own and the generations that will succeed us).

In order to contribute to intensify the debate around the need to establish a research agenda that takes into account the complexity of such phenomena, in this article, we present a proposal for analyzing the formation and transformation of political behaviors in articulation with the processes of intergenerational transmission of social positions throughout different stages of life. Therefore, it is a theoretical approach with methodological implications, which is organized around the questioning of the functioning of the mechanisms of transmission and inheritance that are set in motion in the constitution of frames of perception and evaluation of reality, which, in turn, they result in certain ways of interpreting and reacting to political events.

Referring this discussion to the scope of intergenerational relations means radicalizing the idea that political behaviors are the result of a complex transaction between the dispositions assimilated throughout the processes of socialization and the challenges presented by social, economic and political circumstances, in specific historical contexts; which, in turn, boost processes of resocialization and reflexivity based on assessments (conscious and unconscious) of the present moment, as well as the possibilities of constituting expectations for the future.

Finally, it is worth noting that assuming this theoretical perspective also requires methodological investments in the production of data, quantitative and / or qualitative, that articulate macro and microstructural dimensions in understanding the transmission mechanisms experienced in multiple socializing instances, with emphasis on the specificities in function of the social positions of the groups studied. 


\section{Authors' Contributions}

Problematization and conceptualization, Tomizaki K and Silva MGV; Methodology, Tomizaki K and Silva MGV; Analisis, Tomizaki K and Silva MGV; Writing, Tomizaki K and Silva MGV.

\section{Notes}

1. According to Bréchon (2006), opinions are related to ideas, such as statements or comments on a given subject or taking a position on an ongoing debate in society. Behaviors, in turn, refer to acts related to politics, such as voting. Finally, attitudes refer to a more general, perennial and profound disposition than the previous two dimensions - it refers, above all, to a set of orientations and dispositions internalized by individuals, which base their opinions and behaviors. In this article, we will use the term "political behavior" to designate these three levels of the relationship with politics.

2. According to Mannheim, chronological contemporaneity is not enough to define belonging to a generation. Thus, the formation of generational groups presupposes that individuals who simultaneously participate in life events and experiences capable of creating bonds between them. "Only the same picture of historical-social life allows the situation defined by births in chronological time to become a sociologically relevant situation» (MANNHEIM, [1928]1990, p. 52).

3. According to Bourdieu, the field "is a microcosm, that is, a small, relatively autonomous social world within the great social world. It will find a large number of properties, relationships, actions and processes that are found in the global world, but these processes, these phenomena, take on a particular form there. This is what is contained in the notion of autonomy: a field is an autonomous microcosm within the social macrocosm. Autonomous, according to etymology, means that it has its own law, its own nomos, which has in itself the principle and the rule of its operation. It is a universe in which evaluation criteria that are proper to it operate and that would not have validity in the neighboring microcosm. A universe that obeys its own laws, which are different from the laws of the ordinary social world" (BOURDIEU, 2011, p. 195).

4. The notion of habitus, reworked in relation to its Aristotelian-Thomistic origins, in Bourdieu's work, fulfills the function of relating the individual and social dimensions. It is a system of (pre) dispositions acquired in the processes of socialization. "A product of history, habitus produces the practices, individual and collective, therefore, of history, according to the schemes engendered by history; it guarantees the active presence of past experiences that, deposited in each organism in the form of schemes of perception, thought and action, tend, more securely than all formal rules and explicit rules, to guarantee conformity practices and their constancy over time" (BOURDIEU, 2009, p. 90).

5. It is a concept coined by André Singer, which designates a political agenda to fight poverty, the activation of the internal market, however, without contesting the interests of capitalism, which led to a realignment of the electorate, bringing Lula's leadership closer with the Brazilian subproletariat (SINGER, 2012; 2018).

6. Although it is not our objective to discuss who would be responsible for the political education of children and adolescents, it is worth drawing attention to this debate in the face of the Brazilian political situation, in which we have seen the advancement of conservative thinking with continuous attacks against critical, political and diverse education in schools, through, for example, attempts to implement the "Escola Sem Partido" project. (PENNA, 2016; SEVERO; GONÇALVES; ESTRADA, 2019). 


\section{References}

ALMEIDA, R. M. As disputas em torno de direitos como um processo educativo: um estudo de caso sobre a ocupação "Novo Pinheirinho" de Embu das Artes, SP. 2017. 143 f. Dissertação (Mestrado em Educação) Faculdade de Educação, Universidade de São Paulo, São Paulo, 2017.

ALWIN, D. F.; FELMLEE, D. H.; KREAGER, D. A. (eds.). Social networks and the life course. Integrating the development of human lives and social relational networks. [S. 1.]: Springer, 2018.

ATTIAS-DONFUT, C. Sociologie des générations: l'empreinte du temps. Paris: Universitaire de France, 1988.

ATTIAS-DONFUT, C. Rapports de générations: transfert intrafamiliaux et dynamique macrosociale. Revue Française de Sociologie, Paris, v. 41, n. 4, p. 643-684, 2000. https://doi.org/10.2307/3322701

ATTIAS-DONFUT, C.; WOLFF, F. C. La dimension subjective de la mobilité sociale. Population, Paris, a. 56, n. 6, p. 919-958, 2001. https://doi.org/10.2307/1534747

BARROS, A. T. Educação e legislação: desafios para o aprendizado político e a cultura democrática. Educação \& Sociedade, Campinas, v. 37, n. 136, p. 861-872, set. 2016. https://doi.org/10.1590/es0101-73302016112841

BAQUERO, M.; BAQUERO, R. V. A.; MORAIS, J. A. Socialização política e Internet na construção de uma cultura política juvenil no sul do Brasil. Educação \& Sociedade, v. 37, n. 137, p. 989-1008, 2016. https://doi. org/10.1590/es0101-73302016166022

BASTOS, P. N. MST e Escola Nacional Florestan Fernandes: formação, comunicação e socialização política. Intercom: Revista Brasileira de Ciências da Comunicação, São Paulo, v. 40, n. 2, p. 129-142, ago. 2017. https:// doi.org/10.1590/1809-5844201728

BERNARDIA, L.; HUININKB, J.; SETTERSTEN JR., R. The life course cube: a tool for studying lives. Advances in Life Course Research, Oxford, v. 41, p. 1-13, sep. 2019. https://doi.org/10.1016/j.alcr.2018.11.004 BORGES, A.; VIDIGAL, R. Do lulismo ao antipetismo? Polarização, partidarismo e voto nas eleições presidenciais brasileiras. Opinião Pública, São Paulo, v. 24, n. 1, p. 53-89, 2018. https://doi. org/10.1590/1807-0191201824153

BOURDIEU, P. Questions de politique. Actes de la Recherche en Sciences Sociales, Paris, v. 16, p. 55-89, sep. 1977.

BOURDIEU, P. A economia das trocas simbólicas. São Paulo: Perspectiva, 2004.

BOURDIEU, P. O poder simbólico. Rio de Janeiro: Bertrand Brasil, 2005.

BOURDIEU, P. O senso prático. Petrópolis: Vozes, 2009.

BOURDIEU, P. O campo político. Revista Brasileira de Ciência Política, Brasília, n. 5, p. 193-216, jan.-jul. 2011. https://doi.org/10.1590/S0103-33522011000100008

BOURDIEU, P.; WACQUANT, L. Réponses. Paris: Seuil, 1992.

BOY, D. Origine sociale et comportement politique. Revue Française de Sociologie, Paris, v. 19, n. 1, p. 73-102, 1978. https://doi.org/10.2307/3320954 
BRÉCHON, P. Valeurs de gauche, valeurs de droite et identités religieuses en Europe. Revue Française de Sociologie, Paris, v. 47, n. 4, p. 725-753, 2006. https://doi.org/10.3917/rfs.474.0725

BRENNER, A. K. Do potencial à ação: o engajamento de jovens em partidos políticos. Pro-Posições, Campinas, v. 29, n. 1, p. 239-266, abr. 2018. https://doi.org/10.1590/1980-6248-2016-0120

CARVALHO-SILVA, H. H. A dimensão educativa da luta de mulheres por moradia no Movimento dos Trabalhadores Sem Teto de São Paulo. 2018. 219 f. Tese (Doutorado em Educação) - Faculdade de Educação, Universidade de São Paulo, São Paulo, 2018.

CASTRO, L. R.; GRISOLIA, F. S. Subjetivação pública ou socialização política? Sobre as articulações entre o "político" e a infância. Educação \& Sociedade, Campinas, v. 37, n. 137, p. 971-988, dez. 2016. https://doi.org/10.1590/ es0101-73302016167363

DARMON, M. La socialisation. Paris: Armand Colin, 2015.

DIAS, A. L.; KERBAUY, M. T. M. Engajamento cívico e escolaridade superior: as eleições de 2014 e o comportamento político dos brasileiros. Revista de Sociologia e Política, Curitiba, v. 23, n. 56, p. 149-181, 2015. https://doi. org/10.1590/1678-987315235607

DUBAR, C. La socialisation. Construction des identités sociales et professionnelles. Paris: Armand Colin, 2002.

ELDER JR., G. H.; GIELE, J. Z. (eds.). The craft of the life course research. New York: The Guilford Press, 2009. 372 p.

FERRAZ, S. E. Voto e classe: notas sobre alguns estudos recentes. Opinião Pública, São Paulo, v. 15, n. 2, p. 451-477, 2009. https://doi.org/10.1590/S0104-62762009000200007

FUKS, M. Efeitos diretos, indiretos e tardios: trajetórias da transmissão intergeracional da participação política. Lua Nova, São Paulo, n. 83, p. 145-178, 2011. https://doi.org/10.1590/S0102-64452011000200006

FUKS, M. Atitudes, cognição e participação política: padrões de influência dos ambientes de socialização sobre o perfil político dos jovens. Opinião Pública, São Paulo, v. 18, n. 1, p. 88-108, jun. 2012. https://doi.org/10.1590/ S0104-62762012000100005

FUKS, M. Explicando os efeitos de programas de socialização política: a experiência do Parlamento Jovem no Brasil. Opinião Pública, São Paulo, v. 20, n. 3, p. 425-449, dez. 2014. https://doi.org/10.1590/1807-01912014203425

FUKS, M.; CASALECCHI, G. A. Expandindo o conceito de competência política: conhecimento político e atitudes democráticas na América Latina. Revista de Sociologia e Política, Curitiba, v. 26, n. 68, p. 61-74, 2018. https:// doi. org/10.1590/1678987318266802

FUKS, M. et al. Qualificando a adesão à democracia: quão democráticos são os democratas brasileiros? Revista Brasileira de Ciência Política, Brasília, n. 19, p. 199-219, abr. 2016. https://doi.org/10.1590/0103-335220161908

FUKS, M.; PAULINO, R. O.; CASALECCHI, G. A. Socialization and political regimes: the impact of generation on support for democracy in Latin America. Brasilian Political Science Review, São Paulo, v. 12, n. 1, p. 1-22, 2018. https:// doi.org/10.1590/1981-3821201800010001

FUKS, M.; PEREIRA, F. B. Informação e conceituação: a dimensão cognitiva da desigualdade política entre jovens de Belo Horizonte. Revista Brasileira de Ciências Sociais, São Paulo, v. 26, n. 76, p. 123-143, jun. 2011. https://doi. org/10.1590/S0102-69092011000200007 
FUKS, M.; CASALECCHI, G. A.; RIBEIRO, E. A. Determinantes contextuais da coesão do sistema de crenças democrático: evidências a partir da América Latina. Revista Brasileira de Ciências Políticas, São Paulo, Brasília, n. 28, p. 7-32, 2019. https://doi.org/10.1590/0103-335220192801

GIMENES, E. R.; BORBA, J. Adesão à democracia e apartidarismo na América Latina: análise multidimensional. Revista Mediações, Londrina, v. 24, p. 167-183, 2019. https://doi.org/10.5433/2176-6665.2019v24n3p167

GROPPO, L. A.; BORGES, L. F. Grupo evangélico na universidade: práticas formativas, identidade religiosa e relações políticas. Religião \& Sociedade, Rio de Janeiro, v. 38, n. 3, p. 173-196, dez. 2018. https://doi. org/10.1590/0100-85872018v38n3cap08

LAGROYE, J. La socialisation politique. La pensée vivante d'Annick Percheron. Revue Française de Science Politique, Paris, a. 44, n. 1, p. 129-136, 1994.

LAHIRE, B. Le travail sociologique de Pierre Bourdieu. Dettes e critiques. Paris: La Découverte, 2001.

LIMA, A. M. P. Limites da tolerância na educação para a democracia: o programa Câmara Mirim - Plenário. Educação e Pesquisa, São Paulo, v. 46, e213265, 2020. https://doi.org/10.1590/s1678-4634202046213265

MANNHEIM, K. (1928). Le problème des générations. Paris: Nathan, 1990.

MARTINS, L. M.; BARROS, A. T. Juventude e educação para a democracia: relatos de egressos do Parlamento Jovem Brasileiro. Revista de Sociologia e Política., v. 26, n. 66, p. 49-78, jun. 2018. https://doi. org/10.1590/1678-987318266603

MAYER, N. In memoriam: l'apport d'Annick Percheron à la sociologie. Revue Française de Sociologie, Paris, v. 1, n. 34, p. 125-133, 1993.

MORENO, G. G. Juventude e vida associativa nas periferias de São Paulo. Caderno CRH, Salvador, v. 31, n. 84, p. 581-599, dez. 2018. https://doi.org/10.1590/s0103-49792018000300010

MUXEL, A. Moi, toi et la politique: amour et convictions. Paris: Seuil, 2008.

MUXEL, A. La politique au fil de l'âge. Paris: Presses de Sciences Po, 2011. 312 p.

MUXEL, A. La politique dans la chaîne des générations. Quelle place et quelle transmission? Revue de P'OFCE, Paris, v. 2, n. 156, p. 29-41, 2018. https://doi.org/10.3917/reof.156.0029

MUXEL, A.; PERCHERON, A. Histoires politiques de famille: premières illustrations. Life Stories. Paris: Presses de Science Po, 1985. v. 1.

NICO, M. Transição biográfica inacabada. Transições para a vida adulta em Portugal e na Europa na perspectiva do curso de vida. 2011. 361 f. Tese (Doutorado em Sociologia) - Iscte, Instituto Universitário de Lisboa, Lisboa, 2011.

OKADO, L. T. A.; RIBEIRO, E. A.; LAZARE, D. C. M. Partidarismo, ciclos de vida e socialização política no Brasil. Pro-Posições, Campinas, v. 29, n. 1, p. 267-295, abr. 2018. https://doi.org/10.1590/1980-6248-2016-0063

OLIVEIRA, M. A.; BIANCHINI, P. Educação Política no Brasil e na Itália, duas histórias, muitos problemas comuns. História da Educação, Porto Alegre, v. 21 n. 52, p. 274-294, maio-ago., 2017. https://doi. org/10.1590/2236-3459/69712 
ORTEGA y GASSET, J. (1923). El tema de nuestro tiempo. Madrid: Revista de Occidente, 1981.

PEIXOTO, V.; RENNÓ, L. Mobilidade social ascendente e voto: as eleições presidenciais de 2010 no Brasil. Opinião Pública, São Paulo, v. 17, n. 2, p. 304-332, nov. 2011. https://doi.org/10.1590/ S0104-62762011000200002

PENNA, F. A. Programa "Escola sem Partido": uma ameaça à educação emancipadora. In: GABRIEL, C; MONTEIRO, A.; MARTINS, M. (org.), Narrativas do Rio de Janeiro nas aulas de história. Rio de Janeiro: Mauad, 2016. p. 43-58.

PERCHERON, A. L'univers politique des enfants. Paris: Armand Colin/Presses de la Fondation Nationale de Science Politique, 1974.

PERCHERON, A. Socialisation et tradition: transmission et invention du politique. Pouvoirs, 1987. p. 43-51. (n. 42: La tradition politique.)

PERCHERON, A. Histoires politiques de famille: premières illustrations. Life Stories. Paris: Presses de Sciences Po, 1988. v. 4.

PERCHERON, A. La socialisation politique. Paris: Armand Colin, 1993.

PETERS, G. Habitus, reflexividade e neo-objetivismo na teoria da prática de Pierre Bourdieu. Revista Brasileira de Ciências Sociais, São Paulo, v. 28, n. 83, p. 47-71, out. 2013. https://doi.org/10.1590/S0102-69092013000300004

PEUGNY, C. La mobilité sociale descendante et ses conséquences politiques: recomposition de l'univers de valeurs et préférence partisane. Revue Française de Sociologie, Paris, v. 47, n. 3, p. 443- 478, 2006. https:// doi.org/10.3917/rfs.473.0443

PEUGNY, C. La dynamique générationnelle de la mobilité sociale. Idées Économiques et Sociales, Paris, v. 1, n. 175, p. 18-24, 2014. https://doi.org/10.3917/idee.175.0018

RENNÓ, L.; TURGEON, M. A psicologia política das classes sociais no Brasil: atributos das atitudes políticas por estratificação e mobilidade social. Dados, Rio de Janeiro, v. 59, n. 1, p. 11-52, mar. 2016. https://doi. org/10.1590/00115258201670

RENNÓ, L.; BORBA, J. Tolerância política no Brasil recente: evolução de indicadores e condicionantes. Caderno CRH, Salvador, v. 32, n. 87, p. 641-657, set. 2019. https://doi.org/10.9771/ccrh.v32i87.23749

RIBEIRO, E. Sentimentos partidários e atitudes políticas entre os brasileiros. Opinião Pública, São Paulo, v. 17, n. 2, p. 333-368, 2011. https://doi.org/10.1590/S0104-62762011000200003

RIBEIRO, E.; CARREIRÃO, Y.; BORBA, J. Sentimentos partidários e antipetismo: condicionantes e covariantes. Opinião Pública, São Paulo, v. 22, n. 3, p. 603-637, 2016. https://doi.org/10.1590/ 1807-01912016223603

ROCHA, E. F. Espaço social e estrutura de classes em regiões metropolitanas brasileiras. Sociedade e Estado, Brasília, v. 33, n. 3, p. 779-801, 2018. https://doi.org/10.1590/s0102-6992-201833030006

ROCHA, E. F. Atitudes políticas e mundos semânticos: um estudo qualitativo sobre a racionalidade aquém das ideologias políticas. Civitas - Revista de Ciências Sociais, Partenon, v. 20, n. 1, p. 85-97, 2020. https:// doi.org/10.15448/1984-7289.2020.1.29912 
RODRIGUES, F. C. Educação e luta pela terra no Brasil: a formação política no Movimento dos Trabalhadores Rurais Sem Terra. Educação \& Sociedade, Campinas, v. 38, n. 138, p. 27-44, jan. 2017. https://doi.org/10.1590/ es0101-73302017165251

SAMPAIO, T.; SIQUEIRA, M. Impacto da educação cívica sobre o conhecimento político: a experiência do programa Parlamento Jovem de Minas Gerais. Opinião Pública, São Paulo, v. 19, n. 2, p. 380-402, nov. 2013. https://doi.org/10.1590/S0104-62762013000200006

SAMUELS, D. As bases do petismo. Opinião Pública, São Paulo, v. 10, n. 2, p. 221-241, 2004. https://doi. org/10.1590/S0104-62762004000200002

SCHLEGEL, R. Educação e comportamento político. Os retornos decrescentes da escolarização brasileira recente. 2010. 324 f. Tese (Doutorado em Ciências Políticas) - Faculdade de Educação, Universidade de São Paulo, São Paulo, 2010.

SEVERO, R. G.; GONCALVES, S. R. V; ESTRADA, R. D. A rede de difusão do movimento Escola Sem Partido no Facebook e Instagram: conservadorismo e reacionarismo na conjuntura brasileira. Educação \& Realidade, Porto Alegre, v. 44, n. 3, 2019. https://doi.org/10.1590/2175-623684073

SINGER, A. Os sentidos do Lulismo. Reforma gradual e pacto conservador. São Paulo: Companhia das Letras, 2012.

SINGER, A. O lulismo em crise. Um quebra-cabeças do período Dilma (2011-2016). São Paulo: Companhia das Letras, 2018.

SINGLY, F. A Apropriação da herança cultural. Educação \& Realidade, Porto Alegre, v. 34, n. 1, p. 9-32, 2009.

SILVA, T. M. Nem tão "Flamengo": questões de posição e o voto no Brasil. Revista de Sociologia e Política, v. 27, n. 69, 2019. https://doi.org/10.1590/1678-987319276905

SILVA, M. G. V. Ferrazópolis: um bairro, duas gerações e a política. 2017. 233f. Tese (Doutorado em Educação) - Faculdade de Educação, Universidade de São Paulo, São Paulo, 2017.

SILVA, M. G. V.; TOMIZAKI, K. O sonho de ser metalúrgico: dimensões da vivência juvenil no ABC Paulista. Linhas Críticas, Brasília, v. 22, p. 86-109, 2016. https://doi.org/10.26512/lc.v22i47.4783

TERRON, S. L.; SOARES, G. A. D. As bases eleitorais de Lula e do PT: do distanciamento ao divórcio. Opinião Pública, São Paulo, v. 16, n. 2, p. 310-337, 2010. https://doi.org/10.1590/S0104-62762010000200002

TOMIZAKI, K. Abordagem geracional no estudo das relações entre família e escola. In: ROMANELLI, G.; NOGUEIRA, M. A.; ZAGO, N. (orgs.). Família \& Escola - novas perspectivas de análise. Petrópolis: Vozes, 2013.p 83-106.

TOMIZAKI, K.; CARVALHO-SILVA, H. H.; SILVA, M. G. V. Socialização política e politização entre famílias do movimento dos trabalhadores sem teto. Educação \& Sociedade, Campinas, v. 37, n. 137, p. 935-954, 2016. https://doi.org/10.1590/es0101-73302016166488

TOMIZAKI, K.; DANILIAUSKAS, M. A pesquisa sobre educação, juventude e política: reflexões e perspectivas. Pro-Posições, Campinas, v. 29, n. 1, p. 214-238, abr. 2018. https://doi.org/10.1590/1980-6248-2016-0126

VANDENBERGHE, F. Os pós-bourdieusianos: retrato de uma família disfuncional. In: VANDENBERGHE, F.; VÉRAN, J. (orgs.). Além do habitus - Teoria social pós-bourdieusiana. Rio de Janeiro: 7Letras, 2016. 
VANDENBERGHE, F.; VÉRAN, J. (orgs.). Além do habitus - Teoria social pós-bourdieusiana. Rio de Janeiro: 7Letras, 2016.

\section{About the Authors}

Kimi Tomizaki is a Professor of Sociology at the Faculdade de Educação da Universidade de São Paulo and in the Postgraduate Program in Education of the same unit (PPGE/FEUSP). Master and Doctor in Education from Universidade Estadual de Campinas and Post-Doctorate by the Centre de Recherches Sociologiques et Politiques, in Paris. Author of the book Ser Metalúrgico no ABC Paulista: Transmissão e Herança da Cultura Operária entre Duas Gerações de Trabalhadores (Centro de Memória da Unicamp/Arte Escrita Editora/ FAPESP).

Maria Gilvania Valdivino Silva is a researcher integrated at the Centro de Investigação e Estudos de Sociologia do Instituto Universitário de Lisboa. Graduated in History by the Universidade Estadual Paulista, Master and Doctor in Education by Faculdade de Educação da Universidade de São Paulo (FEUSP).Develops research in the area of Sociology and Education and acts mainly on the themes of Generations, Families, Political Socialization, Politicization, Popular Classes and ABC Paulista region.

Recceived: 07 aug. 2020

Accepted: 19 nov. 2020 